\title{
Deregulation and Managed Competition in Network Industries
}

\author{
J. Gregory Sidak ${ }^{\dagger}$ and Daniel F. Spulber ${ }^{\dagger \dagger}$
}

The competitive transformation of telecommunications and other network industries in the United States has caused governmental policy makers to be increasingly concerned with the "fairness" of the deregulatory process. In this Essay, Professors Sidak and Spulber offer a set of concrete guidelines that regulators of network industries should follow in removing regulatory controls: To achieve the productive and allocative benefits of competition and to ensure that the transition from regulation to competition is accomplished fairly, regulators should observe the principles of economic incentive, equal opportunity, and impartiality. Only by treating incumbents and entrants symmetrically and resisting the temptation to "manage" competition, Professors Sidak and Spulber argue, will the regulators ensure that the deregulatory process in network industries will yield all of the benefits of market competition.

Introduction 118

I. Benefits of Deregulation..................................................................... 120

II. The Economic Incentive Principle .......................................................122

A. Incentives for Voluntary Exchange and Investment ..........................122

B. Regulatory Opportunism and the Cost of Capital.............................123

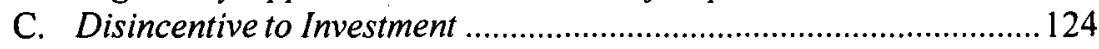

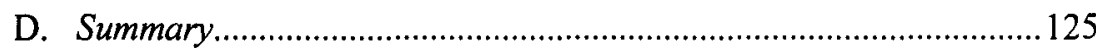

III. The Equal Opportunity Principle .......................................................... 125

A. The Economic Basis for Achieving the Benefits of Competition

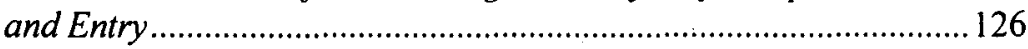

B. The Incumbent Should Have the Same Pricing Flexibility as Entrants

C. Limits on Pricing Flexibility Can Create Inefficiencies in Entry

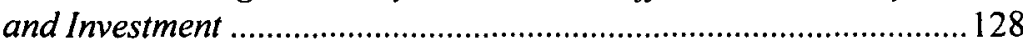

D. The Regulator Should Eliminate Vertical Cross-Subsidies ................130

E. Unbundling Requirements Should Not Create Incumbent Burdens

$\dagger$ F. K. Weyerhaeuser Fellow in Law and Economics, American Enterprise Institute for Public Policy Research; Senior Lecturer, Yale School of Management. This Essay is based on a chapter from our book Deregulatory Takings and the Regulatory Contract: The Competitive Transformation of Network Industries in the United States, which was published in 1997 by the Cambridge University Press.

t† Thomas G. Ayers Professor of Energy Resource Management and Professor of Management Strategy, J. L. Kellogg Graduate School of Management, Northwestern University.

Copyright $(\mathcal{O} 1998$ by Yale Journal on Regulation 


\section{F. Elimination of Restrictions on Service Offerings by the Incumbent LEC \\ G. Caveats Concerning the Evolving Standard of Universal Service.... 134

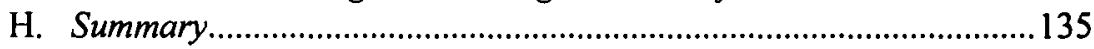

IV. The Impartiality Principle ...................................................................136

A. Regulation Is a Proxy for Competition, Not a Replica of It ................138

B. The Infant Industry Argument .........................................................141

C. Implications for the Design of Rules Governing Access and

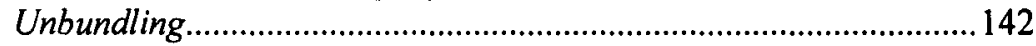

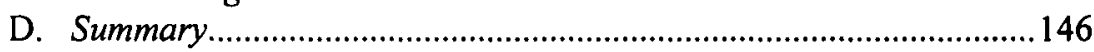

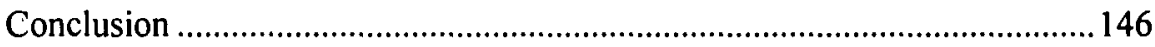

Introduction

How should regulators approach the competitive transformation of network industries? The temptation is to "manage" the competitive transition to determine the outcome of competition. Thus, paradoxically, deregulation often brings increased regulatory intervention in the marketplace and correspondingly greater administrative costs and market inefficiencies. The result is neither fish nor fowl, neither a regulated market nor a competitive one. The benefits of competition do not materialize. Partial deregulation distorts economic incentives far worse than do traditional rate-of-return regulation or newer forms of incentive regulation. The staffs and budgets of the regulatory agencies swell as they undertake the impossible task of managing markets. The problem is akin to privatization in planned economies. Government policy makers must be willing to forsake power and influence over the economy, and to trust what they sometimes view as the "chaos" of the marketplace.

Regulators are concerned with achieving competition "fairly," yet markets are known for their efficiency properties, rather than the equity of their outcomes. ${ }^{1}$ Economists may posture as purists and assert that regulators are misguided to pursue any goal other than economic efficiency. However correct that position may be as a matter of theory, it does not take the institutional setting of regulation as it really is. Consequently, although economists may consider the definition of "fair competition" to be an oxymoronic undertaking, regulators need an operational definition of fairness that does not attempt to specify outcomes, a set of objectives that does not perpetuate regulation, but, rather, lets it recede as competition progresses. In this Essay, we propose three general principles for providing such a definition, thus facilitating the regulator's role in the competitive transformation of network industries.

1. The California Public Utilities Commission, for example, "shall take steps to ensure that competition in telecommunications markets is fair and that the state's universal service policy is observed." CAL. PUB. UTIL. CODE $\$ 709.5$ (West 1975 \& Supp. 1997). 
Free-market competition will likely bring significant benefits to consumers by enhancing productive efficiency of companies in telecommunications, electric power, and other network industries. Competition will increase the variety of products and services offered and stimulate technological innovation. Achieving the benefits of market allocation, however, does not mean that regulators should transfer income from regulated utility investors to consumers. Regulators should not confuse such income transfers with efficiency gains. Instead, regulators should establish basic rules for an orderly transition to competition that rely on competitive innovation and cost cutting as the sources of consumer benefits. To achieve the full benefits of competition while preserving fairness, regulators should observe three fundamental principles.

Economic incentive. The regulated incumbent would not undertake significant expenditures to perform its regulatory service obligations or continue to incur such expenses without economic incentives. Preserving economic incentives requires cost recovery for past, present, and future regulatory obligations. Eliminating cost recovery for regulatory obligations will induce free riding by entrants and regulators, and will make it difficult for regulators to achieve future agreements with private firms. The consequences of reducing or eliminating those economic incentives would be to raise the incumbent firms' cost of capital, to reduce the quality of their service, to discourage their innovation and investment, and, ultimately, to deprive markets of their competitive effort and technology.

Equal opportunity. To achieve the benefits of competition fairly requires that regulations fall evenly on both competitive entrants and incumbents. In practice, that even-handedness means that incumbent burdens must be either dismantled or shared equally across market participants, and that any competitive flexibility possessed by entrants must be accorded to incumbents as well.

Impartiality. Regulatory commissions cannot "pick winners" in terms of technology, products and services, individual companies, or market institutions. Regulators can achieve the benefits of competition only by refraining from market interventions that favor particular competitors, by avoiding attempts to manage competitive outcomes, and by dismantling regulation if demonstrably competitive alternatives exist.

A consistent application of these three principles would provide an essential set of guidelines for the restructuring of regulations governing network industries, yielding the benefits of competitive markets. For ease of exposition, much of our discussion is cast in terms of local telephony and local exchange carriers (LECs), although our analysis is intended to extend equally to investor-owned electric utilities, as well as to other investor-owned public utilities that may face partial or total deregulation of their network industry.

In Part I we outline the benefits of deregulation, while in Part II we review the principle of economic incentive. It states that if deregulation deprives an incumbent investor-owned utility of a reasonable opportunity to earn a fair return on its past investments, then such a utility would be robbed 
of the economic incentive necessary to spur new investments. Thus, an important competitor in the deregulated world would potentially be rendered ineffective.

In Part III we outline the principle of equal opportunity. That principle requires that regulators accord the incumbent an opportunity to compete that is equal to that given to new entrants if deregulation is to achieve the benefits of competition. Regulatory rules enacted in pre-deregulatory regimes that unduly burden the incumbent utility must be transformed. Incumbent burdens, such as mandated horizontal and vertical cross-subsidies, line-of-business restrictions, and asymmetric service obligations, must be transformed to meet the requirements of a deregulated world. Otherwise, incumbent utilities not enjoying the flexibility to adjust their prices and services would not serve as viable competitors. Limits on incumbents' price and service flexibility, we argue in Part III, also create inefficiencies in entry and investment.

In Part IV we discuss the principle of impartiality, which calls on regulators not to "pick winners" in terms of technology, products, services, and, ultimately, firms. Regulators cannot predict outcomes of technological innovation or consumer choice. Competitive markets are much better suited for choosing "winners" and "losers." Market incentives are also sufficient to allow competition to flourish without regulators' attempts to safeguard "nascent" competitors.

\section{Benefits of Deregulation}

Competition is desirable in local exchange telecommunications for the same reasons that it is desirable in any market. Competitive markets are the preferable economic mechanism for achieving allocative, productive, and dynamic efficiency. Allocative efficiency is present when goods and services are allocated to the uses in which they have the highest value. Productive efficiency is present when producers use goods and services in such a manner as to minimize costs subject to technological constraints. Dynamic efficiency refers to decisions made over time, including efficiencies in investment and technological innovation. Deregulation can achieve greater efficiency in entry and investment decisions, lower administrative costs, elimination of pricing distortions, increased innovation, and greater opportunities for customer choice. Under regulation, the incumbent LEC invested in facilities to perform its obligation to serve and to achieve regulatory objectives, including the provision of universal service. The possibility of stranded costs, as regulators permit competition in the market for local telephony, indicates that such investment may not have been economically efficient-that is, the incremental benefits to consumers may not exceed the incremental costs of the investment. Through prudency reviews and used and useful tests, ${ }^{2}$ regulators attempted to guard against inefficient investment that did not satisfy regulatory criteria.

2. Sec Daniel F. Spulber, Regulation and Markets 269-71 (1989). 
Those safeguards, however, were significantly different from a full test of economic efficiency. The deregulation of telecommunications now forces companies investing in facilities for access, switching, transmission, and other functions to subject their investment decisions to a more rigorous market test and to determine whether the investment project is tailored to the task at hand and justified by the value of the services that customers will receive.

Deregulation reduces or eliminates the administrative costs associated with traditional rate-of-return regulation, as well as those associated with incentive regulation. In particular, deregulation obviates rate hearings, which entail costs for the regulator's staff as well as for the utilities, the intervenors for customers, and competitors. To achieve these benefits, the regulator must reduce its oversight role in competitive segments of the formerly regulated marketplace, rather than create complex rules requiring increased intervention in market activities.

Deregulation enhances economic efficiency through elimination of crosssubsidies. Cross-subsidies cause economic losses by distorting customers' decisions because prices fail to convey accurate signals about costs. Services that receive the subsidy are priced too low, encouraging excessive purchases of these services and displacing potentially more efficient alternatives. Services that generate the subsidy are priced too high, discouraging purchases of such services, and leading customers to seek alternatives that otherwise would not be purchased.

Deregulation promotes innovation. The many competitors entering the market will offer myriad competing solutions to telecommunications problems. These solutions may involve not only new technologies, but also widely differing mixtures of software, equipment, network connections, and transmission media. Under regulation, universal service requirements and the absence of competition led to a "one-size-fits-all" approach. Regulated telecommunications providers concentrated in large part on upgrading system capacity, enhancing reliability, and achieving the objectives mandated by regulatory commissions. In contrast, a competitive market responds to changing customers' preferences and tailors capacity, reliability, and service offerings to the disparate needs of individual market segments.

Deregulation can enhance customers' choices. Under the monopoly of the former Bell System, customers could purchase only basic types of telephones. The proliferation of customer premises equipment (CPE) since the breakup of AT\&T and the FCC's deregulation of CPE indicates how the market responds to customers' requirements by offering a variety of choices and investing in research and development to widen those choices still further. ${ }^{3}$

As deregulation proceeds, some urge regulators to take an activist role, to manage the transition so as to "promote" or "protect" competition. However, that view is misguided. Regulation should recede as competition progresses.

3. See Robert W. Crandall, After the Breakup 11, 88-97, 149-53 (1991); Peter W. Huber ET AL., THE GEODESIC NeTWORK II: 1993 REPORT ON COMPETITION IN THE TELEPHONE INDUSTRY 2.12$2.13,6.52-6.71(1992)$. 
There is no need for regulators to promote competition because the returns that firms expect to earn from serving customers provide sufficient incentives for those firms to compete in the provision of telecommunications services. Indeed, an attempt to manage competition not only entails administrative costs, but can also prevent the market from achieving the benefits of competition that regulators wish to attain for consumers. ${ }^{4}$

\section{The Economic Incentive Principle}

The economic incentive principle requires that the regulatory commission give the LEC the incentive to discharge its regulatory obligations. We consider the consequences for telecommunications markets of competitive rules that would deprive the incumbent LEC of the economic incentives to compete in the market, invest in expansion and upgrading of facilities, maintain quality of service, and obtain investment capital. We then examine the implications of that principle for the design of competitive rules governing the local telecommunications market.

\section{A. Incentives for Voluntary Exchange and Investment}

Economic analysis of how consumers, companies, investors, and other market participants make choices rests on the notion of response to incentives. A consumer purchases goods and services only if he anticipates gains from trade-that is, only if he expects the transaction to yield positive net benefits for him. Companies supply products and services in the hope of earning economic profits-that is, earnings beyond what is necessary to keep all factors of production employed in their current use. It follows that a supplier will not invest in a transaction unless the supplier has an expectation that the returns from the transaction will recover all economic costs, including a competitive return to invested capital. Investors supply funds to projects in expectation of earning a competitive return on their investment-that is, a return that equals the return on other investment opportunities of comparable risk. Markets function on the basis of these economic incentives.

Economic incentives imbue contract law. Parties generally will not make promises gratuitously - that is, without economic incentives to supply goods or services or other performance specified in the contract. Damage remedies for breach of contract also contain economic incentives. Without such incentives, a

4. Elsewhere we have written of the need to protect private firms from anticompetitive behavior by the U.S. Postal Service. See J. Gregory Sidak \& Daniel F. SPulber, Protecting Competition from THE POSTAL MONOPOLY (1996). The situation of the Postal Service is entirely distinguishable from that of a regulated investor-owned utility. The Postal Service is a public enterprise that cannot be assumed to maximize profit; the regulatory authority to which it is subject lacks the essential powers of a typical state public utility commission; it enjoys not only a statutory monopoly, but also many other privileges and immunities relative to private firms; and it exercises the authority to define the scope of its own monopoly. Moreover, there is no indication that the delivery of letter mail will soon undergo a transition to competition. Similar assessments hold with respect to the Canadian postal monopoly. See J. Gregory Sidak \& Daniel F. Spulber, Monopoly and the Mandate of Canada Post, 14 YALE J. ON REG. 1 (1997). 
party to the contract would be tempted to behave in an opportunistic fashion. He would break the contract (without cost to himself) when it was advantageous for him to do so; and by unilaterally forcing a renegotiation of the contract terms, he would take advantage of the irreversible commitments made by the other party to the contract.

As we explained in detail elsewhere, legal protections of private property rest on economic incentives. 5 Likewise, without property protections, individuals and businesses would not have an incentive to invest in improvements of their property. Without property protections for the residual returns from investment projects, companies would not have the incentive to undertake these projects. Economic incentives, therefore, affect the production and investment behavior of any firm, whether or not that firm is subject to regulation. Federal and state regulation of public utilities should take account of the economic incentive principle. A utility would not undertake the extensive investments required to provide regulated service within its franchise region without the necessary economic incentives. Removing such incentives would eliminate the impetus for a regulated company to undertake new expenditures to satisfy regulatory obligations. ${ }^{6}$

\section{B. Regulatory Opportunism and the Cost of Capital}

As the telecommunications industry becomes deregulated, the incumbent LEC cannot be asked to provide services in the competitive market at regulated prices that are uncompensatory, meaning prices that preclude any reasonable opportunity for full cost recovery. The destruction of economic incentives that would result from depriving a utility of reasonable opportunity to earn a fair return on its investment would reduce the utility's ability-and hence its willingness - to continue providing the service. By a "fair return" we mean the return that investors expect to receive in comparison with competitive alternatives of comparable risk. Accordingly, we use the terms "fair return" and "competitive return" interchangeably. If competitive rules deny the utility the reasonable opportunity to earn a fair return on its investments made under the previous regulatory regime (and thus cause stranded costs to materialize), there will be additional efficiency problems created by the regulator's attenuation of economic incentives.

If the regulator's rule for deregulating the industry destroys the economic incentives facing the utility, then the regulator will create a temptation for opportunism and free riding; it will also raise the cost of capital, deprive the market of some effective competitors, reduce the quality of service, and deter innovation. Concerns over reputational effects normally keep regulatory commissions from behaving opportunistically. Such opportunistic behavior would produce several related consequences. If it were made to anticipate

5. See J. Gregory Sidak \& Daniel F. Spulber, Deregulatory Takings and Breach of the Regulatory Contract, 71 N.Y.U. L. REv. 851, 933-36 (1996).

6. See id. 
renegotiation of rate agreements after it had made irreversible investments, a regulated firm would have an incentive to underinvest. Moreover, by raising the risks to investors through such opportunistic behavior, the regulator would necessarily raise the cost of capital to the regulated firm. That risk premium would apply both to debt financing and equity financing of utility investments. ${ }^{7}$ In short, contrary to the simplistic assessment that stranded costs are sunk costs whose recovery does not affect the current and future decisions of economic actors, it is clear that the recovery of the utility's historic costs (also called embedded costs) is an issue whose treatment by the regulator during the transition to competition affects the utility's investment decisions and cost of capital on a forward-looking basis.

To the extent that some services provided by utilities continue to be regulated, the regulator's failure to address the problem of stranded costs harms the long-term interests of ratepayers. If the regulator does not protect the expectation interest of utility investors, then customers in competitive telecommunications markets may receive short-term gains at the long-term expense of other customers in segments of the market that continue to be regulated. That scenario represents an income transfer from one group of customers to another, rather than a benefit of deregulation.

\section{Disincentive to Investment}

Reducing returns on investment and denying recovery of past investments would cause incumbent LECs to reduce or eliminate the construction of transmission and switching facilities needed to supply telecommunications services. That disincentive to investment would halt or slow the growth of existing networks and could reduce expenditures for maintenance and upgrading of transmission technology. Although competitors could be expected to supply some of the needed transmission technology, the extent of such supply of new facilities will depend critically on the pricing of unbundled network elements and wholesale services. Moreover, even if competitors do become facilities-based entrants, the market would again be denied the benefits of the presence of incumbent LECs as substantial and experienced rivals. With reduced market participation by the incumbent LECs, customers would have fewer choices of suppliers.

It might be argued that because capital facilities are nonrecoverable or sunk costs, the incumbent LECs would continue to operate as long as their earnings equaled or exceeded their operating costs. Could not the incumbents depreciate or "write off" all nonrecoverable capital costs already incurred without harming the incentives for continued operation? This perspective overlooks the continuing need for maintenance, upgrading, and eventual replacement of capital facilities. If deprived of a return to capital facilities after capital has

7. For a more technical discussion of the effects of imperfect regulatory commitment on the utility`s capital structure and its cost of capital, see Yossef Spiegel \& Daniel F. Spulber, The Capital Siructure of a Regulated Firm, 25 RAND J. ECON. 424 (1994). 
been sunk in irreversible investments, or if faced with reduced returns to investments already made, any economically rational company will eliminate or reduce similar capital investments in the future. Instead, the company will invest in more promising telecommunications ventures in Chile or New Zealand or Hungary. Such elimination or reduction of investment would diminish the quality of service for customers relying on the incumbent LECs' obligation to serve.

The incumbent LECs invest not only in facilities and maintenance of service quality, but also in the creation and deployment of innovative services. A firm invests in the risky process of product innovation only if it anticipates earnings on new or enhanced services. The incumbent LECs also invest resources in "process" innovation that enhances efficiency or reduces costs. Without those returns to innovation, the incumbent LECs would have a reduced incentive to devote resources to product and process innovation.

\section{Summary}

By adhering to the economic incentive principle, the regulator will ensure that it will not precipitate a reduction in the quality of service, that it will maintain incentives for innovation, that its policies will not increase the incumbent LECs' cost of capital, and that one class of customers will not shift costs to core customers during any transition period. Continuing service requirements imposed on the incumbent LECs, particularly the obligation to provide unbundled network access, should be priced in a fashion that maintains the incumbent LECs' incentives to provide service. To do so requires compensating the incumbent LECs for all of their continuing and future regulatory obligations to serve, including their universal service obligation.

\section{The Equal Opportunity Principle}

To achieve the economic benefits of competition, regulators must give the incumbent LECs an opportunity to compete that is equal to that given entrants. The equal opportunity principle requires regulations to fall evenly on entrants and incumbents. Therefore, regulators should modify or eliminate rules that prevent incumbents and entrants alike from exercising flexibility in pricing, service offerings, investment, and choice of technology. The equal opportunity principle also has two closely related implications. First, regulatory requirements imposed on the incumbent LECs that the regulator wishes to continue when the market is opened to competition should be imposed on all entrants. Second and conversely, any flexibility and freedom from regulation that entrants possess should be extended to the incumbent LECs by removing pertinent regulations that apply exclusively or disproportionately to the incumbent LECs.

Regulations create costs and constraints for market participants. Regulations that favor incumbents over entrants will create regulatory barriers 
to entry that reduce market competition and potential entry. Reduced competition, in turn, can create inefficiencies in the protected market, with or without regulatory safeguards, in comparison with the outcome of a competitive market. According to George Stigler's famous definition, barriers to entry are costs imposed on entrants that are not present for incumbents. ${ }^{8}$ The two main types of barriers to entry are sunk costs and government regulation. ${ }^{9}$ Sunk costs are a barrier to entry if entrants need to make irreversible investments in capacity, while incumbents have already incurred such costs. Government regulation that takes the form of rules applying unevenly to incumbents and entrants can create additional costs for entrants. Government regulation can also restrict market entry outright.

In contrast, regulations that favor entrants over the incumbents thereby limiting the incumbents' ability to compete. Incumbent burdens are costs that are imposed on incumbents but are not present for entrants. Generally, such costs refer to utility regulations that are not imposed on entrants, including (1) continuing obligations to serve that are imposed on the incumbents; (2) liabilities undertaken by the incumbents in response to regulatory requirements or in reasonable expectation of a continuation of regulatory policy; and (3) restrictions on the incumbents' pricing and their product and service offerings. Incumbent burdens provide incentives for inefficient bypass of the incumbents' transmission facilities by taxing the incumbents and by creating corresponding subsidies for the entrants. ${ }^{10}$ As one of us has previously noted:

The benefits of entry, including survival of low-cost producers and efficient pricing, may not be achieved if the incumbent must satisfy regulations not imposed on entrants. Costly duplication of capital facilities may occur. Loss of economies of scope may create welfare losses for the remaining customers served by the incumbent firm. Thus, deregulation does not merely require competitive opportunities for entrants; it also requires an equal lifting of restrictions placed on established firms. ${ }^{.1}$

Thus, the equal opportunity principle requires designing regulatory rules that do not create either undue entry barriers or incumbent burdens.

\section{A. The Economic Basis for Achieving the Benefits of Competition and Entry}

Regulators can achieve economic benefits of competition and entry only if all companies have an equal opportunity to compete. Competition means that

8. See George J. Stigler, The ORganization of Industry 67 (1968). Other eminent economists have embraced Stigler's definition. See, e.g., William J. Baumol \& Robert D. Willig, Fixed Cost, Sunk Cost, Eniry Barriers and Sustainability of Monopoly, 95 Q.J. ECON. 405 (1981).

9. For additional discussion of barriers to entry, see SPULBER, supra note 2, at 40-42.

10. See Paul W. MacAvoy et al., Is Competitive Entry Free?: Bypass and Partial Deregulation in Natural Gas Markets, 6 YAL. J. ON REG. 209, 228 (1989).

11. SPULBER, supra note 2, at 624. 
the most efficient and creative firms prosper. The market cannot be expected to discover the best competitors unless all companies begin on an equal regulatory footing.

The incumbent LEC is an important competitor with technological experience, management expertise, knowledge about customers in its service regions, ready access to financial capital, and transmission facilities. To deprive the market of the incumbent LEC's services and expertise would reduce competition, disadvantage consumers, and reduce the competitive stimulus to entrants. Moreover, it is not necessary to limit the incumbent LEC's ability to compete as a means of encouraging new entry. As in any other business, the market returns that can be earned by providing telecommunications services are reward enough to encourage entry. Placing restraints on the incumbent LEC that confer an advantage on entrants will only impede competition.

\section{B. The Incumbent Should Have the Same Pricing Flexibility as Entrants}

When companies compete to provide local telecommunications services, prices are driven down toward costs. Regulators, however, will not achieve the full benefit of competition if they continue price controls on the incumbent LEC. The maintenance of price controls-not only price caps, but also price floors-prevents the incumbent LEC from responding competitively to the price offers of entrants. This minimum-price constraint can prevent the incumbent's participation in important market segments, for it provides an umbrella under which entrants can price without fear of retaliation from the incumbent. $^{12}$

Price constraints on the incumbent also effectively discourage competition. It is well known that in price regulation a ceiling can become a floor and a floor can become a ceiling. ${ }^{13}$ With regulatory price floors imposed on the incumbent LEC, entrants could price just below the floor, tacitly coordinate their prices, and capture customers from the incumbent LEC while avoiding competition among themselves. Eliminating the incumbent LEC's price floor injects the incumbent into the market as a credible rival and allows the market price to fall freely, as true competition requires.

Price caps will discourage competition as well if regulators maintain them for the incumbent but do not require them for entrants. If a price cap were not to allow the incumbent to recover its full economic costs, it could induce the incumbent to exit the market segment covered by the price cap (if it were permitted by law to do so), again depriving the market of an important competitor.

Further, a price constraint imposed on an unbundled service should not

12. For an analogous assessment of the untoward consequences of the FCC's asymmetric regulation of $A T \& T$ in the interexchange market, see PAUL W. MACAVOY, THE FAILURE OF ANTITRUST AND REGULATION TO ESTABLISH COMPETITION IN LONG-DISTANCE SERVICES 83-103 (1996). J.)

13. See. e.g., Vogel v. American Soc'y of Appraisers, 744 F.2d 598, 604 (7th Cir. 1984) (Posner, 
allow an entrant to offer the service as part of a bundle that competes effectively with the incumbent's bundled service, strictly due to the price constraint. Unbundling should not imply that regulation prevents the incumbent from offering any bundled services; rather, unbundling should merely enable entrants to have access to components of the incumbent's bundled service. If there are competitive markets for those components, regulators should eliminate the price constraints. In any case, if prices for components continue to be regulated, they must allow the incumbent to recover its costs. Otherwise, if entrants can buy the components in a way that is noncompensatory for the incumbent, the result will simply be an income transfer from the incumbent's shareholders to the entrants' shareholders and the exit of the incumbent from market segments, again reducing the vigor of competition.

To increase profits and to achieve competitive advantage, companies continually strive to lower their costs and prices. They do so by acquiring new technology and by deploying their technology in the most efficient manner. Price caps ${ }^{14}$ and sharing rules ${ }^{15}$ are meant to provide incentives for regulated firms to improve cost efficiency because companies can retain a share of their cost savings from cost-reducing investment ${ }^{16}$ Price caps and sharing rules lose some of their incentive properties, however, if applied in a competitive market. If the incumbent LEC must share the gains from investment while competitors may retain all of their earnings, the incumbent will have a smaller incentive to provide the service. The sharing rules will function as a tax on the incumbent LEC's earnings, thus reducing the incumbent's return to investment compared to its competitors. These rules, therefore, should be eliminated so that the incumbent LEC and entrants have equal incentives to reduce costs, invest, expand, and compete for customers.

\section{Limits on Pricing Flexibility Can Create Inefficiencies in Entry and Investment}

Regulators should not constrain the incumbent LEC's price responses to entry beyond what the antitrust laws already provide. The incumbent LEC faces a set of incumbent burdens associated with the regulatory rate structure. ${ }^{17}$ Those burdens concern the horizontal rate structure (the relative rates charged to the utility's customer classes) and the vertical rate structure (the relative prices for network components and retail services). ${ }^{18}$ Entrants are free to set prices as market conditions change and to negotiate contractual agreements and discounts with individual customers. In contrast, the incumbent must file tariffs

14. See David E.M. Sappington \& Dennis L. Weisman, Designing Incentive Regulation for THE TELECOMMUNICATIONS INDUSTRY 80-88 (1996) (discussing the nature of price caps).

15. See id. at $75-80$ (discussing the nature of sharing rules).

16. See id.

17. See J. Gregory Sidak \& Daniel F. Spulber, Deregulatory Takings and the Regulatory CONTRact: The COMPETItive Transformation of Network Industries in the United STATES 30-47 (1997).

18. See id. 
(which cannot be changed without advance notice, perhaps of one month or more) with the regulator and charge prices that are nondiscriminatory. ${ }^{19}$ Regulated rate structures, therefore, constrain the timing and substance of the price responses available to the incumbent.

The utility's rate structure is generally based on cost allocation rules that determine the relative prices charged to various customer groups, ${ }^{20}$ or contains price caps that continue to reflect past cost allocation rules. ${ }^{21}$ Those cost allocation rules often entail cross-subsidies. ${ }^{22} \mathrm{~A}$ regulated break-even rate structure is said to be free of cross-subsidies only if the revenues from each service, or combination of services, are less than or equal to the stand-alone cost of that service, or combination of services. ${ }^{23}$ Under cost-of-service regulation, with a break-even rate structure, business customers are subsidizing other services if the revenues from business customers exceed the stand-alone costs of serving those customers. In that case, business customers would be better off if they were to pay the stand-alone price of such service. Therefore, the presence of cross-subsidies provides an opportunity for bypass of the incumbent. A stand-alone entrant can undercut the incumbent's rates and serve major customers, while still earning economic profit. ${ }^{24}$

At least initially, entrants serve those customers who had provided crosssubsidies. That selection bias in the class of customers served by entrants can lead to uneconomic bypass. The incumbent's facilities may be able to serve the market at the least cost, but because regulation distorts relative prices across the incumbent's customer classes, the prices charged to some of these classes do not reflect the incumbent's cost advantage. That artificial disparity between cost and regulated price allows some types of inefficient entry to occur that a competitive market would not tolerate. Total industry capacity may, as a consequence, be excessive. The industry's total costs of service can rise because the incumbent's facilities are not priced competitively and thus are employed below their most efficient scale of operation.

If rate restrictions remain on the incumbent $L E C$, the outcome that results when regulators open the local telecommunications market to competition will

19. See, e.g., 47 U.S.C.A. $\$ \$ 202-203$ (West Supp. 1997).

20. See Sidak \& Spulber, supra note 5, at 908-09; see also Jurisdictional Separations Reform and Referral to the Federal-State Joint Board, CC No. 80-286 (to be codified at 47 C.F.R. pt. 36) (Fed. Communications Comm'n, proposed Oct. 2, 1997) (summarized at 62 Fed. Reg. 59,842 (1997)).

21. See SIDAK \& SPULBER, supra note 17 , at 40-47.

22. See id.

23. See William J. Baumol et al., Contestable Markets and the Theory of Industry STRUCTURE 352-53 (rev. ed. 1988); William J. Baumol \& J. Gregory SidaK, TOWARDS Competition IN LOCAL TELEPHONY 81 (1994).

24. The regulated rate structure of the regional Bell operating companies (RBOCs), with high rates charged to business customers, has created opportunities for selective bypass of the local network, particularly by competitive access providers such as Metropolitan Fiber Systems (MFS) and Teleport Communications Group (TCG), which primarily serve large business customers. See MFS COMMUNICATIONS Co., FORM 10-K FOR THE FISCAL YEAR ENDED DECEMBER 31, 1995, at 1, 11 (1996); TELEPORT Communications Group, Inc. Prospectus for 23,500.000 Shares of Class a Common Stock (June 3. 1996); Affidavit of Glenn A. Woroch. United States v. Western Elec. Co., 1994-2 Trade Cas. (CCH) I 70,704 (D.D.C. 1994) (No. 82-0192 (HHG)). 
not necessarily be efficient. The rate structure will prevent the incumbent LEC from responding to competition. That problem is exacerbated by cost-ofservice regulation that is based on recovery of sunk costs, or incentive regulation that continues to reflect embedded cost components. Valuation of the rate base using historical costs, rather than market value, further increases the distortion. Moreover, if the regulated utility faces a two-tier market divided into core and business customers, with price restrictions remaining in both market segments, its pricing decisions in the business market will be affected.

\section{The Regulator Should Eliminate Vertical Cross-Subsidies}

The incumbent LEC's rate structure also contains vertical cross-subsidies: Some components, functions, or elements of telecommunications services are sold below cost and receive subsidies from other components or elements. ${ }^{25}$ For transfer revenues ${ }^{26}$ to be free of vertical cross-subsidies, the transfer revenue for a service must not exceed its stand-alone cost and must cover the incremental cost to the vertically integrated firm to produce the service. ${ }^{27}$

Suppose that an input $X$ is used in the production of a retail service $Q$. Let $C(X)$ be the stand-alone cost of producing $X$. Let $C(Q)$ be the cost of producing $Q$ using the input $X$, but excluding the cost of producing the input $X$. Finally, let $C$ be the total cost to a vertically integrated firm of producing both the input $X$ and the final service $Q$ using the input $X$. Then, the transfer revenues must not exceed the stand-alone cost of the input, $C(X)$. Moreover, the transfer revenues must be greater than or equal to the incremental cost of the input to the vertically integrated firm, which equals $C$ minus $C(Q)$.

Clearly, the regulated revenues from the final service should equal the total cost of providing the final service. Suppose that the input and the final service are unbundled, so that a purchaser buying the final service pays the sum of two charges. Then, if transfer revenues are subsidy-free, the separate charge for the final service cannot exceed the stand-alone cost of providing the downstream service (excluding the cost of the input). Moreover, the separate charge for the final service must be greater than or equal to the incremental cost to the vertically integrated firm of producing the final, vertically integrated service. If regulators adhere to these conditions, they will eliminate vertical crosssubsidies in the incumbent LEC's rate structure.

\section{E. Unbundling Requirements Should Not Create Incumbent Burdens}

Most products and services, from automobiles to piano lessons, are bundles of attributes or features. Customers benefit from the convenience of purchasing a range of products and services from a single supplier offering lower

25. See SIDAK \& SPULBER, supra note 17. at 509-10.

26. By "transfer revenues," we mean the revenues paid by one division or subsidiary of a company for an input produced by another division or subsidiary of the company.

27. This concept is defined formally in SPULBER, supra note 2, at 120. 
transactions costs through "one-stop shopping" and the bundling of products and services. Companies compete by offering creative packages of goods and services that enhance customer convenience. Regulations preventing the incumbent LEC from bundling, or denying it access to services that are an important component of the product bundle, block incumbent entry into the market for these services and can reduce the vigor of competition in such services.

If the incumbent LEC cannot provide interexchange services, for example, other firms will be able to resell bundles of services that include interexchange services without facing competition from the incumbent. The interexchange carrier that bundles services will bid customers away by offering the convenience of one-stop shopping, not because the carrier has any inherent competitive advantage in the provision of local exchange services, or interexchange services for that matter. Rather, the competitive advantage arises due to regulations that impose asymmetric unbundling requirements: The incumbent LEC cannot offer such a bundle while the interexchange carrier can. As a consequence, seemingly neutral unbundling requirements can determine the outcome of competition. The unbundling requirements become particularly onerous when coupled with quarantines that prevent the incumbent LEC from selling or providing interexchange services. The result is diminished competition for a broad range of services relative to a market in which the incumbent LEC has an equal opportunity to compete.

Besides harming competition, asymmetric unbundling requirements are necessarily arbitrary. Excessive unbundling eliminates the reduced transaction costs that result from bundling features that increase consumer convenience. Furthermore, standardized bundles of product features and services lower the marketing and sales costs of the supplier, thus creating cost efficiencies. Forced unbundling is not a means by which regulators can replicate the functioning of competitive markets. To the contrary, because bundling is a standard aspect of competition, forced unbundling can achieve precisely the opposite result by eliminating product and service bundles that otherwise would have been offered in an unregulated market.

\section{F. Elimination of Restrictions on Service Offerings by the Incumbent LEC}

Competitive companies increase their returns by offering customers differentiated products. Customers benefit from greater product variety because they can purchase products that are better tailored to their preferences. Restrictions on the types of products and services that the incumbent LECs can offer again deprives the market of potentially effective competitors. ${ }^{28}$ Furthermore, if those competitors would be able to bring specialized service capabilities and competencies to the market, then the variety of service offerings could decline appreciably. Customers would lose the opportunity to 212.

28. The principal example is the interLATA restriction. See MACAvoY, supra note 12, at 175- 
have the full range of choices of telecommunications carriers. Reduction in competition would raise prices for given levels of services, resulting in lower net benefits to consumers and reduced access to services.

A competitive market can exacerbate the unintended consequences of regulation. For example, the Modification of Final Judgment (MFJ) ${ }^{29}$ contained a line-of-business restriction that prevented any regional Bell operating company (RBOC) from providing long-distance service from one local access and transport area (LATA) to another. The Department of Justice attempted to justify that restriction as a means of enhancing competition in the long-distance market. $^{30}$ The restriction, however, had the unintended (but, in retrospect, entirely predictable) consequence of reducing competition in the long-distance market. ${ }^{31}$ Unless the successor provision in Section 271 of the Telecommunications Act of $1996^{32}$ is construed in a more competitive manner, it too will have the effect of impairing the incumbent LECs' ability to compete in local exchange, much to the detriment of consumers.

Rate regulation that creates cross-subsidies and other constraints on the pricing of the incumbent LECs place them at a disadvantage relative to entrants. To achieve the benefits of competition, regulators must give all competitors equal pricing flexibility. If allowed to persist, cross-subsidies built into the incumbent LECs' rate structure will encourage entrants to target the incumbents' above-cost customers in the markets for intraLATA toll services, switched access, vertical features, and the like. The incumbent LECs would be unable to change their regulated rate structure in response to such targeted entry and their shareholders would be forced to absorb the economic loss arising from reduced revenues and fewer customers.

Quarantines, such as those contained in the $\mathrm{MFJ}^{33}$ and continued in the "checklist" provisions of Section 271 of the Telecommunications Act of $1996,{ }^{34}$ could prevent the RBOCs from offering competitive service packages. Interexchange carriers entering the local exchange market may bundle the RBOCs' local exchange services (purchased on an unbundled or wholesale basis) with their own long-distance service and thus offer their customers onestop shopping. In other words, an interexchange carrier could package its own interLATA service with an RBOC's local exchange service that had been sold at wholesale (or recreated through the recombination of unbundled network elements) at less than that service's true economic cost. Given the prohibition against a public utility's unilaterally modifying its rate structure, the asymmetric ability of interexchange carriers to bundle services would place the RBOC at a severe competitive disadvantage. Regulators should not permit that

29. See United States v. AT\&T Co., 552 F. Supp. 131, 225-34 (D.D.C. 1982). See generally

Michael K. Kellogg et al., Federal Telecommunications Law (1992).

30. See United States v. AT\&T Co., 552 F. Supp. at 225-34.

212.

31. See KELLOGG ET AL., supra note 29, at 199-248; see also MACAVoY, supra note 12, at 175-

32. 47 U.S.C.A. $\$ 271$ (West Supp. 1997).

33. See United States v. AT\&T Co., 552 F. Supp. at 225-34.

34. See 47 U.S.C.A. $\$ 271$ (c)(1)(B) (West Supp. 1997). 
distorted version of competition to obtain. Regulators should prevent an entrant from exploiting both the horizontal subsidies that regulation has imposed across the incumbent LECs' services and the vertical cross-subsidies built into the LECs' regulated transfer prices.

The regulatory obligation to serve should not distribute the social objectives of regulation unevenly between the incumbent LECs and the entrants. The entrants generally can establish their own service areas, which allows them to target pockets of high-volume customers within the incumbent LEC's service area, while neglecting less profitable customers in rural or highcost locations. Meanwhile, the incumbent LECs retain the burden of serving those customers whom entrants find unprofitable to serve. ${ }^{35}$

Regulators should carefully specify an entrant's service requirements. If the entrant's application to the regulator to provide local exchange service specifies a class of customers that the entrant intends to serve, and all customers outside that class could be denied the entrant's service regardless of their proximity to the entrant's facilities, such selectivity in the entrant's offering of service would disadvantage the incumbent LECs in favor of entrants. Again, entrants would provide service only to the most profitable customers and would leave the high-cost, low-volume users to be served by the incumbent LECs. The regulator should, therefore, create symmetric service obligations or provide a common fund to compensate the incumbent LECs for the full costs of satisfying their universal service obligation.

Another burden that the incumbent LEC shoulders is to serve as the carrier of last resort. ${ }^{36}$ Mandating that the incumbent LEC alone act as the carrier of last resort forces the firm to hold capacity in reserve to meet demand at peak load. An entrant, however, need not hold capacity in reserve because it does not serve as the carrier of last resort; the entrant can simply purchase capacity for resale from the incumbent LEC at peak demand. The entrant thus benefits from the implicit form of insurance provided to its customers without charge by the incumbent LEC's standby service.

Unless the regulatory framework adjusts to actual and impending competition, it can create burdens that artificially place the incumbent at a competitive disadvantage. The regulator should eliminate these asymmetric rules and avoid adopting new ones that deny the incumbent an equal opportunity to compete. For example, the lesser degree of pricing flexibility allowed the incumbent LEC enables entrants to adjust their prices in response to changing market conditions much faster than the incumbent. The difference is a regulation-induced competitive advantage for entrants that comes at the incumbent's expense. In addition, regulators typically do not require entrants to provide cost studies to support their proposed rates, even though the incumbent LEC must

35. See J. Gregory Sidak \& Daniel F. Spulber, The Tragedy of the Telecommons: Government Pricing of Unbundled Network Elements Under the Telecommunications Act of 1996, 97 CoLUM. L. REV. 1081, 1120-21 (1997). If the regulated price is below a new entrant's cost, entry will not occur.

36. See Dennis L. Weisman, Default Capacity Tariffs: Smoothing the Transitional Regulation Asymmetries in the Telecommunications Market, 5 YALE J. ON REG. 149, 151 (1988). 
provide such studies. ${ }^{37}$ Entrants derive an additional competitive advantage over the incumbent by virtue of their unreciprocated access to its cost studies. Furthermore, without proper safeguards applied equally to all local exchange carriers, entrants (which will include established firms such as AT\&T and Time-Warner) can exploit the regulatory constraints on the incumbent LEC in their design of pricing programs and service offerings. For example, the coststudy requirements borne by the incumbent LEC create delays that entrants can easily exploit in marketing new services. Unencumbered by these rules, entrants can perform market research on new products while the incumbent LEC is still awaiting the regulator's permission.

\section{G. Caveats Concerning the Evolving Standard of Universal Service}

The Telecommunications Act of 1996 codified and expanded the concept of universal service into an evolving standard that advances with new technology. ${ }^{38}$ If, as a matter of social policy, it is decided that a particular group of consumers should be subsidized in its use of interactive broadband services, it is preferable for government to fund those subsidies explicitly through its power to tax and appropriate funds from the public treasury. Regulators should resist the temptation to fund the subsidies by distorting the prices charged to other consumers of interactive broadband services.

Some of the most notable statements by senior policy makers concerning telecommunications policy have referred to "information haves" and "information have-nots." 39 These remarks imply that any disparity in access to interactive broadband services must be avoided as part of a technologically revised policy of universal service. The goal of universal access, however, is undermined by several potential problems. First, it is doubtful that, relative to private firms, government policy makers will have superior knowledge of the interactive broadband services that consumers will ultimately demand. If private firms do not even know what the "information haves" are likely to demand, the government can hardly be expected to know what to prescribe to improve the relative standing of the "information have-nots."

Second, consumer tastes are heterogeneous across the population. Consequently, it would not necessarily reflect a failure of government policy or an inequitable distribution of income if some consumers demanded sophisticated communications products while others did not. Forcing all consumers to receive the same package of services is likely to cause providers

37. For a description of the existing regulatory regime with regard to incumbent LEC cost studies see Jurisdictional Separations Reform and Referral to the Federal-State Joint Board, at I 6, CC No. 80-286 (to be codified at 47 C.F.R. pt. 36) (Fed. Communications Comm'n, proposed Oct. 2, 1997) (summarized at 62 Fed. Reg. 59,842(1997)).

38. See 47 U.S.C.A. $§ 254$ (West Supp. 1997). The discussion that follows draws upon Robert W. Crandall \& J. Gregory Sidak, Competition and Regulatory Policies for Interactive Broadhand Networks, 68 S. CAL. L. REv. 1203, 1217-20 (1995).

39. See, e.g., Edmund L. Andrews, The Media Business: New Plan for Phone and Cable, N.Y. TIMES, Dec. 22, 1993, at DI (reporting a speech by Vice-President Albert Gore). 
of interactive broadband services to gravitate to the lowest common denominator. The result will be that interactive broadband services will be less diverse and less responsive to niche markets.

Third, the "information have-nots" may lack other important resources that impede their economic advancement, such as literacy, education, and work experience. If so, then the substantial cost of subsidizing interactive broadband access to their homes may actually divert the public's attention and financial resources from other policies that would materially improve conditions for these persons in a shorter period of time. It may be counterproductive, as well as foolhardy, to oversell the ability of the information superhighway to cure social ills.

Fourth, if universal service becomes the predominant public policy concern regarding the deployment and operation of interactive broadband networks, regulators may inadvertently foreclose the possibility of intermodal competition among rival networks in their attempt to use the information superhighway as a tool to redistribute income. A report by McKinsey \& Company speculated on how that state of affairs could arise:

[T] he [Clinton] Administration has ... stressed the need for universal access as a way to avoid the segregation of society into information "haves" and "have nots." This goal is likely to conflict with facilitiesbased competition. Market forces may well lead to the early deployment of two full-service networks in affluent areas, but preclude investment in costly-to-serve rural areas or impoverished inner-city neighborhoods. As the potential for conflict becomes more apparent, there may be a shift in regulatory policy toward a more heavily regulated, "one wire" approach, which avoids redundant investments in a second broadband network and gives greater emphasis to the policy objective of universal access. ${ }^{40}$

From the perspective of maximizing consumer welfare, it would be regrettable if the commitment to empowering disadvantaged segments of the population were to have the unintended effect of denying all segments of the population the substantial benefits that would flow from having two or more facilitiesbased providers of interactive broadband services rather than one.

\section{H. Summary}

The equal opportunity principle postulates that regulators should restructure regulation to assure that all competitors enter the market on an even regulatory footing. Regulators should dismantle any incumbent burdens that deprive incumbent utilities of an equal opportunity to compete. For example, if regulators insist on market intervention to achieve universal service objectives,

40. John Hagel III \& Thomas R. Eisenmann, Navigaring the Mullimedia Landscape, MCKINSEY Q.. June 22, 1994, at 45 . 
they should create a common fund, with equitable contributions made by all competitors, to cover the cost of such service. Moreover, it is essential for regulatory commissions to eliminate horizontal and vertical cross-subsidies and grant incumbents the same pricing or service flexibility offered to new entrants.

IV. The Impartiality Principle

Once all market participants receive from regulators an equal opportunity to compete, what should happen after deregulation occurs and competition continues to increase? For markets to function properly, government cannot direct the outcomes without incurring high administrative costs and constraining customer choice and company innovation. The impartiality principle is, therefore, a fundamental component of public policy: Regulators should not "pick winners" in terms of technology, products and services, companies, or market institutions.

Deregulation should not be viewed as a type of industrial policy in which government attempts to dictate or even gently nudge market outcomes, favoring one technology or mode of transmission over another. Regulators should not create artificial boundaries between modes of transmission, or artificial distinctions between services, customers, or carriers. Moreover, the deregulatory process should not be designed to favor specific services such as voice, data, or video transmission.

By definition, the outcomes of technological innovation are unanticipated. An important benefit of competition is that rival companies create unexpected products and services. That result is particularly salutary because neither regulators nor anyone else can easily predict the choices of individual customers.

The impartiality principle is a policy prescription that recognizes the process of "creative destruction" that Joseph A. Schumpeter described in $1942 .^{41} \mathrm{He}$ argued that the pursuit of market power is a creative, dynamic force that "incessantly revolutionizes the economic structure from within, incessantly destroying the old one, incessantly creating a new one." rivalry as "the essential fact about capitalism." that a firm's acquisition or possession of market power can be fleeting. In the most famous passage of Schumpeter's classic discussion on creative destruction, he wrote:

[S] ince we are dealing with an organic process, analysis of what happens in any particular part of it-say, in an individual concern or industry - may indeed clarify details of mechanism but is inconclusive beyond that. Every piece of business strategy acquires its true

41. See Joseph A. Schumpeter, Capitalism, Socialism and Democracy 81-86 (3d ed. 1950).

42. Id. at 83 .

43. Id. 
significance only against the background of that process and within the situation created by it. It must be seen in its role in the perennial gale of creative destruction; it cannot be understood irrespective of it or, in fact, on the hypothesis that there is a perennial lull.

But economists who, ex visu of a point in time, look for example at the behavior of an oligopolistic industry - an industry which consists of a few big firms-and observe the well-known moves and countermoves within it that seem to aim at nothing but high prices and restrictions of output are making precisely that hypothesis. They accept the data of the momentary situation as if there were no past or future to it and think that they have understood what there is to understand if they interpret the behavior of those firms by means of the principle of maximizing profits with reference to those data. The usual theorist's paper and the usual government commission's report practically never try to see that behavior, on the one hand, as a result of a piece of past history and, on the other hand, as an attempt to deal with a situation that is sure to change presently-as an attempt by those firms to keep on their feet, on ground that is slipping away from under them. In other words, the problem that is usually being visualized is how capitalism administers existing structures, whereas the relevant problem is how it creates and destroys them. ${ }^{44}$

Unless government imposes artificial barriers to market entry, as it did in 1956, when an antitrust decree forbade AT\&T to enter the computer business, ${ }^{45}$ actual and potential competitors will repeatedly challenge and inevitably supplant the incumbent. That version of competition, Schumpeter explained, "commands a decisive cost or quality advantage and ... strikes not at the margins of the profits and outputs of the existing firms but at their foundations and their very' lives." 46 Such competition, moreover, "acts not only when in being but also when it is merely an ever-present threat. It disciplines before it attacks." ${ }^{47}$ Creative destruction thus implies that basing regulatory or antitrust policy on static analysis of today's market conditions can be seriously misleading.

If they must base regulatory intervention on predictions of dynamic trends in markets, government officials should proceed with the knowledge that their crystal ball may be just as cloudy as the one employed by the drafters of the AT\&T divestiture. Government cannot ordain how technologies of communications shall evolve, nor can government expect to remove the economic distortions that its regulations have created simply by ordering the industry to be restructured. The world's largest providers of telecommunications and information services are now locked in a tournament to offer

\footnotetext{
44. Id. at 83-84.

45. See United States v. Western Elec. Co., 1956 Trade Cas. (CCH) $\mid 68,246$ (D.N.J. 1956)

46. SCHUMPETER, supra note 41 , at 84 .

47. $\quad l d$. at 85 .
} 
consumers a new generation of interactive broadband services. It would harm consumers for regulators to exclude any firm from that tournament. The impartiality principle envisions that the regulator will impartially permit firms to compete for the market dominance that Schumpeter described, an ephemeral dominance from which they may be unseated by the next wave of product innovation.

\section{A. Regulation Is a Proxy for Competition, Not a Replica of It}

There is no need for regulators to protect or safeguard competition. Market incentives are sufficient to allow competition to flourish. If regulators act in a partial manner, either by picking winners or by protecting less successful firms from their own inefficiency, then the benefits of competition will diminish. Moreover, antitrust laws serve to protect competition from monopolization and other anticompetitive practices. Regulatory attempts to supplant this role of antitrust would preempt its proper functioning.

Excessive regulatory intervention during the competitive transformation of network industries often seems designed to promote competitors, not competition. That distinction should be familiar from antitrust, where the view that antitrust exists to protect "small dealers and worthy men" 48 has been replaced by an understanding that antitrust should set the rules of the game, not determine its outcome. ${ }^{49}$

As we have explained at length elsewhere, ${ }^{50}$ the Federal Communications Commission, while singing the praises of competition and market allocation of resources, promptly proposed after the enactment of the Telecommunications Act of 1996 an entirely new genre of price regulation for inputs in local telephony. ${ }^{51}$ That price regulation was on a scale unprecedented in the telecommunications industry or any other U.S. industry, for that matter. The regulation of markets for resale and unbundled network services supplants the determination of pricing and service offerings by firms competing in the market. This new form of government intervention extends regulation beyond the previous system addressing final telecommunications services to include new controls of the underlying factors of production. Entrants into local telephony, such as the major interexchange carriers and cable television system operators, may now urge regulators to determine how productive inputs shall be priced, provisioned, and employed in the production of telecommunications services. Telecommunications regulation has thus expanded to encompass control of technology, capital equipment, and other productive inputs. Contrary to the popular conception created by the passage of the Telecommunications Act, ${ }^{52}$ the new unbundling obligations of the 1996 legislation represent a

48. United States v. Trans-Missouri Freight Ass'n, 166 U.S. 290, 323 (1897).

49. See, e.g., Continental T.V., Inc. v. GTE Sylvania, Inc., 433 U.S. 36 (1977)

50. See Sidak \& Spulber, stupra note 35 .

51. See lowa Utils. Bd. v. FCC, 120 F.3d 753 (8th Cir. 1997), cert. granted sub nom. AT\&T Co. v. lowa Utils. Bd., 118 S. Ct. 879 (1998).

52. See Sidak \& Spulber, supra note 35 , at 1159. 
significant and qualitative extension of regulation from outputs to productive inputs.

In the wake of the 1996 telecommunications legislation, some economists endorsed the proposition that regulators are necessary to "jumpstart" competition in the new environment of mandatory network access. ${ }^{53}$ Professor John Mayo, for example, argued that regulators should implement only those regulations that achieve competitive outcomes:

A primary goal of public utility pricing is to achieve an allocation of resources similar to that which would result in competitive markets. Because effectively competitive markets automatically generate efficient prices (the fundamental virtue of the invisible hand), it is essential that regulators understand the basic characteristics of such prices if they are to replicate competitive outcomes in regulated markets. $^{54}$

Thus, in Professor Mayo's view, regulators of telecommunications markets should seek to achieve an outcome similar to the one achieved by a competitive market. Regulators are to achieve that desired outcome, however, not by letting the forces of competition operate freely, but instead by relying upon some unspecified system of government "replication." This prescription raises two fundamental questions.

First, is a competitive allocation of resources the primary goal of regulators? There are many reasons to doubt the validity of this proposition. Economic analysis establishes that cross-subsidies in the prices offered by a company cannot survive in a competitive market. ${ }^{55}$ No firm in a competitive market would voluntarily cross-subsidize its own product offerings because it would have an incentive to cease offering services whose incremental revenues did not cover their incremental costs. Moreover, competitive entrants will "cherry-pick" incumbent LECs' customers of services providing crosssubsidies. ${ }^{56}$ Regulated markets, however, differ markedly from competitive markets in that the former commonly contain cross-subsidies, as regulators seek to achieve perceived fairness and other social objectives, such as universal service. ${ }^{57}$ Regulated prices for local telecommunications services, for example, typically contain cross-subsidies due to geographic averaging, subsidies from business customers to residential customers, and subsidies from vertical

53. See, e.g., David L. Kaserman \& John W. Mayo, An Efficient Avoided-Cost Pricing Rule for Resale of Local Exchange Services, 11 J. REG. ECON. 91 (1997) (summarizing their testimony at the AT\&T hearings).

54. Opening Testimony of John W. Mayo on behalf of AT\&T Communications of Cal., Inc. at 24, (Cal. Pub. Util. Comm'n) (No. R.93-04-003, I.93-04-002) (June 14, 1996).

55. See BAUMOL ET AL., supra note 23, at 202; see also BAUMOL \& SiDAK, supra note 23, at 70-72 (discussing subsidy-free prices); Gerald R. Faulhaber, Cross-Subsidization: Pricing in Public Enterprise, 65 AM. ECON. REv. 966, 972-76(1975); Sidak \& Spulber, supra note 5, at 911-13.

56. See SIDAK \& SPULBER, stupra note 17, at 90-95.

57. See. e.g. BAUMOL \& SiDAK, supra note 23, at 24-25. 
services to basic services. ${ }^{58}$

Second, could regulators "replicate" competitive outcomes in regulated markets even if they were inclined to do so? It is doubtful. Competitive markets require continual adjustment of prices and product offerings to changes in customer tastes, incomes, and technological innovation. The informational requirements of such adjustments are not compatible with the costly, complex, and protracted administrative procedures that regulatory rulemaking requires. Regulators cannot be expected to react to, let alone anticipate, changes in customer preferences and supplier technology. To the contrary, excessive regulation can discourage innovation and capital investment, and thus lock in obsolete technologies. In short, transaction costs and information processing costs make it unworkable for regulators to attempt to supplant or recreate competitive outcomes. To suggest that regulators can replicate the "invisible hand" of the market fundamentally contradicts Adam Smith's original point that policy makers should not interfere with the functioning of competition:

The statesman, who should attempt to direct private people in what manner they ought to employ their capitals, would not only load himself with a most unnecessary attention, but assume an authority which could safely be trusted, not only to no single person, but to no council or senate whatever, and which would nowhere be so dangerous as in the hands of a man who had folly and presumption enough to fancy himself fit to exercise it. ${ }^{59}$

Regulation is a proxy for competition, not a replica of it. ${ }^{60}$ Rather than attempting to replicate the market, regulators should recognize that achieving market outcomes requires removing regulatory restrictions as telecommunications markets become increasingly competitive. Expanding the scope of regulation will only make it less, not more, plausible that regulators will be able to achieve market outcomes.

Congress, state legislatures, and regulators have opened the local exchange market to competition. ${ }^{61}$ If they now establish unbiased rules that allow entrants and incumbents an equal opportunity to compete, regulators can rely on market incentives to produce competitive outcomes. If regulators are concerned that

58. See Robert W. Crandall \& Leonaro Waverman, Talk is Cheap: The Promise of REgUlatory REForm In NORTH AMERICAN TElECOMMUNICATIONS 94 (1996).

59. ADAM SMITH, THE WEALTH OF NationS 423 (The Modern Library, New York 1937) (1776).

60. One of us has previously advocated with William J. Baumol that regulators should pattern regulation according to the competitive-market standard, which asserts that the regulator's task is to serve as a proxy for competition "to stand in loco competitio, preventing all actions that competition would have precluded, and requiring all courses of economic behavior that competition would have imposed." BAUMOL \& SIDAK, supra note 23, at 28. Just as a guardian who stands in loco parentis cannot replicate for an orphan the essence of his deceased parents, neither can a regulator replicate the essence of a competitive marketplace. Accordingly, the first principle of the competitive-market standard provides: "Where competitive forces are adequate and effective, the regulator should eschew all forms of intervention." $/ d$.

61. See generally ingo Vogelsang \& Bridger M. Mitchell, Telecommunications CompetiTION: THE LAST TEN MILES (1997). 
competition will not be sufficiently vigorous following the removal of entry barriers, then they should rely on price caps and allow competition (if it takes hold) to set prices below the cap. Moreover, the caps should be phased out as rapidly as possible because many factors other than imperfect competition (such as rising input costs, capacity shortages, or product enhancements) can cause market prices to rise. Adjustments to price caps based on productivity and inflation indices are unlikely to achieve the flexibility required for the regulated firm to keep pace with changing market conditions. Rather, it is the spontaneous and natural outcome of private companies, seeking to obtain a competitive return on the investment of their shareholders.

\section{B. The Infant Industry Argument}

One might assert that competition in a newly deregulated market, such as local telephony, differs from competition in other industries because the incumbent LEC has been subject to a regulated monopoly and because competition in the local exchange market is nascent. ${ }^{62}$ The fact that the incumbent LEC held a regulated monopoly in the past is not an indicator that regulators need to promote competition. The fallacy of the conclusion that regulatory nurturing is necessary for competition to blossom can be shown by making a counterfactual assumption that the incumbent LEC acted like a classic monopolist and withheld services, increased prices substantially, and reduced the quality of customer service. Those actions would increase the incentives for the entry of new competitors. Past monopoly, far from being a hindrance to competition, is an important stimulus to competition, as entrants seek to bid away customers by outperforming the pricing, product availability, and service quality of the former monopolist. Past monopoly, therefore, requires no corrective action by regulators in terms of subsidizing, supporting, or otherwise promoting competitors.

Students of economic history will immediately recognize the "nascent competition" argument in a newly deregulated industry as a variation on the "infant industry" argument employed to justify entry barriers in international trade. ${ }^{63}$ The infant industry argument is advanced by those who believe that domestic industry should be subsidized and otherwise protected from international competitors until the domestic industry grows sufficiently. ${ }^{64}$ The argument has little merit, and it certainly does not apply to the regulated network industries. In telecommunications, entrants into local exchange telephony include AT\&T, MCI, Sprint, and others. These entrants are not infants. To the contrary, these companies are notably large, well-established, well-funded, and innovative. They are experienced in telecommunications, and

62. See Sur-rebuttal testimony of Dr. John W. Mayo on behalf of Enron Power Mktg., Inc., (Pa. Pub. Util. Comm'n) (No. R-00973953) (Oct. 10, 1997).

63. See, e.g., Douglas A. Irwin, Against The Tide: An InTEllectual History of Free Trade $116-37(1996)$.

64. See id. 
their competitive efforts are far from nascent. They do not need subsidies, assistance, or special privileges. Even relative newcomers to telecommunications are perfectly capable of purchasing the requisite equipment and obtaining the required technological and marketing expertise to pursue their objectives.

If, contrary to the weight of economic analysis, regulators choose to subsidize entrants, it bears emphasis that that decision in no way answers the question of who should pay the subsidy. In particular, it does not follow logically that the subsidy must be a wealth transfer from the incumbent LEC to entrants. In the United Kingdom, for example, the regulatory body, Oftel, requires British Telecom (BT) to provide interconnection to its network to cable television systems that have telephony capabilities and compete against BT's provision of voice and data services. ${ }^{65}$ Although the interconnection charge includes a component representing the entrant's payment of BT's contribution to universal-service obligations, the Director General of Oftel has exercised his discretion to waive payment of this "access deficit contribution" until the entrant has achieved a market share of 10 percent. ${ }^{66} \mathrm{~A}$ subsidy financed in that manner raises takings concerns of the sort we have analyzed at length elsewhere. ${ }^{67}$ If there is to be a subsidy, it should be politically transparent. The legislature, for example, could explicitly subsidize entrants by paying the incumbent LEC the difference between the price and the economic cost of providing interconnection.

Even if an infant industry argument were applicable to telecommunications, when should advantages for the competitors of the incumbent LEC cease? How would their duration be specified in advance? The government's commitment to ending the entrant's infant-industry status at a certain date or upon the attainment of some objective level of market penetration must be credible and binding. That political task would be difficult to accomplish, however. Consequently, the recommendations for regulatory promotion of competition appear to create open-ended commitments for the regulator. Such open-ended commitments are poorly suited to allowing regulation to recede as competition increases.

\section{Implications for the Design of Rules Governing Access and Unbundling}

As they dismantle entry barriers, regulators should commit to curtailing their future market intervention. They should neither attempt to manage competition nor retain rules that arbitrarily favor one market outcome over another. The competitive market is an allocation mechanism that generates and uses tremendous amounts of information about the preferences and purchasing patterns of individual consumers, as well as the technology and supply patterns

65. See Crandall \& Sidak, supra note 38, at 1235-37; see also VogelSANG \& MiTCHELL, supra note 61 , at 277-96 (discussing interconnection charges for BT).

66. See Crandall \& Sidak, supra note 38, at 1235-37.

67. See Sidak \& Spulber, supra note 5. 
of many diverse competitors. Regulation of a franchise monopoly utility generates a large amount of technical and economic information. Competitive markets that are growing and innovative, however, generate quantities of information that are orders of magnitude greater than what any regulatory commission can assimilate. Regulators must be prepared for the increased complexity of competitive markets by withdrawing entirely from supervision and management of the pricing and other strategic decisions in any market that is demonstrably competitive. The lifting of regulation, of course, does not mean that the incumbent LEC in a newly competitive market is freed of all legal constraints on its conduct. Antitrust law continues to prohibit both exorbitant prices that would result from collusion and excessively low prices that would be set with a predatory intent to expel an efficient rival from the marketplace. ${ }^{68}$

The common name given to selective entry of markets served by an incumbent utility is "cream skimming" or "cherry picking." For a typical incumbent LEC, 80 percent of its revenues may come from 20 percent of its customer accounts, which in turn will be concentrated in metropolitan areas. ${ }^{70}$ Entrants can minimize their marketing costs by focusing on those high-margin customers. Selective entry also reduces the network costs for entrants, particularly facilities-based entrants.

Selective entry is a normal method of market competition that should not be impeded. For such entry to be efficient, however, regulators should not create or perpetuate rules that impair the ability of any firm, including the incumbent LEC, to respond to this form of competition with its own flexible pricing and service offerings. Moreover, the selectivity of entrants should be based on economic considerations such as customer demand and costs of service. It should not be based on regulatory loopholes that encourage the entrant to serve only certain customers or geographic locations so as to avoid the burden of public service obligations. Entry decisions should not be strategic responses by firms to incumbent burdens that competitively handicap the incumbent LEC. If they eliminate cross-subsidies and other service requirements that fall asymmetrically on the incumbent LEC, regulators will allow undistorted market considerations to determine the pattern of competitive entry.

Impartiality further requires that regulators refrain from imposing new product and market definitions on the basis of past regulatory considerations. Perpetuating such distinctions would lead to balkanized markets and would

68. See Brooke Group Ltd. v. Brown \& Williamson Tobacco Corp., 509 U.S. 209, 224-26 (1993); Matsushita Elec. Indus. Co. v. Zenith Radio Corp., 475 U.S. 574, 589 (1986); ROBERT H. Bork, THE antitrust Paradox: A Policy at War with Itself 144-59 (Free Press 1993) (1978); Yale Brozen, Concentration, Mergers, and Public Policy 163, 392 (1982); Richard A. Posner, antitrust LAW: AN ECONomic PERSPeCtive 184-96 (1976); Phillip Areeda \& Donald F. Turner, Predalory Pricing and Related Practices Under Section 2 of the Sherman Act, 88 HARV. L. REV. 697, 718 (1975); Frank H. Easterbrook, Predatory Sirategies and Counterstrategies, 48 U. CHI. L. REV. 263 (1981); J. Gregory Sidak, Debunking Predatory Innovation, 83 COLUM. L. REV. 1121 (1983).

69. See ALFRED E. KAHN, 2 ECONOMICS OF REGULATION 7 (1989).

70. See BAUMOL \& SIDAK, supra note 23, at 11. 
deter both intermodal competition and technological innovation. For example, traditional regulation in telecommunications has distinguished between telecommunications services on the basis of the mode of transmission (copper wire, coaxial cable, or wireless), the type of communication (voice, data, or video), and regulatory customer class (residential or business). ${ }^{71}$ Markets for the transmission of voice, data, video, and other types of information will combine these types of communication in new and unexpected ways, providing specialized services to satisfy the needs of diverse market segments. Regulators should dismantle to the maximum extent possible the artificial distinctions among types of information transmitted so as not to bias the types of products and services that firms will offer to consumers.

California has provided a commendable example of regulatory impartiality by enacting legislation providing that " $[\mathrm{t}] \mathrm{o}$ the extent possible, competition in intraexchange telecommunications markets shall be coincident with competition in video markets." ${ }^{172}$ The statute further provides:

If any local exchange telephone company obtains the right to offer cable television or video dial-tone service within its service territory from a regulatory body or court of competent jurisdiction, any cable television corporation or its affiliates may immediately have the right to enter into the intraexchange market within the service territory of the local exchange carrier by filing for approval of a certificate of public convenience and necessity, if necessary, which shall be expeditiously reviewed by the commission. ${ }^{73}$

Finally, the statute specifies that the California Public Utilities Commission's standards for the interconnection of networks, network unbundling, and service quality applied to the LECs shall apply equally to cable television companies. $^{74}$ Thus, California's legislature stated its laudable intent that competition in video, cable television, and video dial-tone should be fair in that competitors should be free to enter each other's markets and that regulations and standards should apply evenly.

Another area in which regulatory impartiality is sorely needed concerns the boundary between local and long-distance telephony. Distinctions among interexchange, intraLATA toll, and intraexchange service, although having some basis in technology and regulatory history, have little economic foundation. ${ }^{75}$ Regulators should allow companies to offer the full range of services without regard to the distance traveled or the types of switches used.

71. See J. Gregory Sidak, Telecommunications in Jericho, 81 CAL. L. REV. 1209, 1209 (1993) (reviewing Peter W. Huber et AL., The Geodesic Network II: 1993 Report ON COMPETITION IN THE

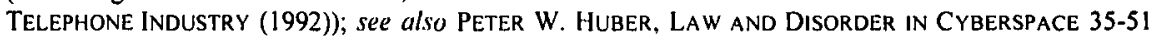
(1997).

72. Cal. Pub. Util. Code $§ 709.5$ (b) (West Supp. 1997).

73. $\$ 709.5(\mathrm{~d})$

74. $\S 709.5(\mathrm{e})$.

75. See KellogG ET AL., supra note 29, at 227-34 (discussing origins of the LATAs). 
Indeed, the clear trend in telecommunications is to erase any distinctions among long-distance, interLATA, intraLATA, or local exchange service. ${ }^{76}$ Companies seek to provide connections between customers-what AT\&T calls "anywhere, anytime" communications. ${ }^{77}$ If regulators continue to impose detailed restrictions on the service offerings of incumbent LECs that do not recognize this evolution in the market, then regulators will place the LECs at a competitive disadvantage and will have effectively, albeit unintentionally, preordained the success or failure of individual firms in the market. The same point applies to modes of transmission, including the twisted copper pair, coaxial cable, fiber optics, cellular, and satellite systems. Technological change in software and switching systems allows the near-seamless integration of networks consisting of diverse transmission elements and the connection of multiple networks with each other. ${ }^{78}$ An incumbent LEC must have the same flexibility as other firms to employ and combine modes of transmission in constructing networks for its services. Any artificial distinctions among modes of transmission or means of switching and routing information across networks will place the incumbent LEC at a competitive disadvantage.

Another issue of impartiality arises with respect to facilities-based competition and resale. A resale market for the facilities of any carrier is desirable for achieving efficient use of existing facilities and efficient investment in new facilities. As we have emphasized elsewhere, however, the rules for unbundling and resale must not place uneconomic requirements on the incumbent LEC. $^{79}$ Excessive unbundling does not enhance economic efficiency. Moreover, government-mandated access to network facilities at rates that do not recover the incumbent LEC's economic costs will induce inefficient decisions by entrants concerning whether to build facilities or merely resell services that use the incumbent's existing facilities. Overpriced services and facilities will encourage underuse of existing facilities by entrants and could induce overinvestment by the incumbent, whereas underpriced services and facilities will force the incumbent to subsidize entrants and could induce its underinvestment in network facilities.

Impartiality requires that all firms involved in either originating, transporting, or terminating calls be compensated on the basis of network usage and services provided. Given the complexity of network interconnection and transactions that will likely emerge in a competitive market, revenue-sharing arrangements should be the outcome of voluntary agreements among carriers, customers, and other market participants. When multiple carriers are involved in the transmission of communications, they should all receive compensation. The regulator should resist allowing traffic flow imbalances to benefit some competitors at the expense of others.

76. See, e.g., A Survey of Telecommunications: The Death of Distance, THE ECONOMIST, Sept. 30, 1995 (special insert).

77. AMERICAN TElePhone and Telegraph Co., 1993 ANNUAL Report.

78. See HUBER, supra note 71 , at 111 .

79. See Sidak \& Spulber, supra note 35 


\section{Summary}

Consistent with the impartiality principle, regulators should not attempt to influence the eventual outcome of competition or to micromanage the evolving telecommunications and electric power markets. Regulators should rapidly phase out their industry oversight and regulatory activities to avoid the possibility of biasing competitive outcomes. To unleash the efficiencies and innovation of competitive markets in telecommunications, for example, regulators should eliminate regulations that draw artificial distinctions among modes of transmission, types of communications, or services that are performed within or across the boundaries of a local access and transport area. It is overwhelmingly an artifact of regulatory convenience rather than economic or technological necessity that regulators continue to draw distinctions among interLATA, intraLATA, and local exchange services. To maintain impartiality and to avoid stifling innovation, regulators should avoid or limit, as much as possible, forced access and unbundling that will reduce the returns to innovation and competitively disadvantage incumbent carriers.

\section{Conclusion}

The Telecommunications Act of 1996 is off to a rocky start because federal and state regulators have been reluctant to relinquish control of the industry. The result has been wrangling between incumbents and entrants before regulatory commissions and in the courts, as well as disagreement between Congress and the Federal Communications Commission over interpretation of the statute. ${ }^{80}$ The resulting litigation will delay the benefits that competition will bring. Federal and state deregulation of the electric power industry lies ahead. It would be unfortunate if legislators and regulators were to repeat in that industry the same mistakes being committed in the competitive restructuring of local telecommunications. In this Essay, we have presented three principles for legislators and regulators to follow to ensure that their deregulation of those two industries will indeed bring consumers the benefits of competition.

The economic incentive principle rests on the recognition that economic gains from trade drive market transactions and that economic incentives underlie the regulatory contract as well. If the competitive rules were to deprive the incumbent LEC of economic incentives, that outcome would harm the firm's ability to enter competitive markets, to raise capital to finance investment projects, to innovate, to provide a diversity of services, and to perform its regulatory obligations.

Regulators cannot achieve the economic benefits of competition without adhering to the equal opportunity principle. They should scrupulously design rules that create no advantage for the entrant over the incumbent, or vice versa,

80. See Iowa Utils. Bd. v. FCC, 120 F.3d 753 (8th Cir. 1997), cert. granted sub nom. AT\&T Co. v. lowa Utils. Bd., 118 S. Ct. 879 (1998). 
but instead place all competitors on an even regulatory footing. Regulators should dismantle regulatory constraints to ensure that any opportunity or independence enjoyed by the entrants extends to the incumbents. Incumbent LECs should receive the same flexibility and autonomy as entrants in choosing their prices, negotiating with customers, altering service offerings, and making other business decisions.

Regulators following the impartiality principle will not interfere with innovative competition. Regulators should resist appeals from entrants to aid their cause by continuing to monitor competitive outcomes. Because competition is a process of innovation, it is not possible for regulators to predict accurately the prices, products, services, technology, and network characteristics that will result. Regulations that are dismantled should remain so. They should not be kept in reserve if the outcomes differ from regulators' expectations. Regulators must not create rules that favor particular companies, technologies, service offerings, or other market outcomes. They should sunset regulations in competitive segments of the local telecommunications market.

In short, by allowing incumbent LECs to compete and perform regulatory obligations, by giving all firms in the local telecommunications market an equal opportunity to compete, and by remaining impartial as competition progresses, regulators will attain the goal of achieving competition fairly. 
